УДК 304.9

Научная статья

DOI 10.18101/2306-630X-2020-1-3-15

\title{
РОССИЯ — ЦЕНТР «БОЛЬШОЙ ЕВРАЗИИ»?
}

\author{
() Осинский Иван Иосифович \\ доктор философских наук, профессор, \\ Бурятский государственный университет имени Доржи Банзарова \\ Россия, 670000, г. Улан-Удэ, ул. Смолина, 24а \\ intellige2007@rambler.ru
}

Аннотация. В статье рассматриваются проблемы формирования и развития социально-философской концепции евразийства: причины, условия, факторы, противоречия, становление данного учения, его основные идеи, а также их создатели - ученые и политики, внесшие наибольший вклад в их разработку. Раскрываются дискуссии вокруг понятий «евразийство», «Евразия», «АТР». Анализируются отношение евразийцев к революции 1917 г., советской власти, преобразования в области экономики, культуры, образования. Подвергается осмыслению понятие «идеократия», его сущность, характер, место в евразийской концепции. Обращается внимание на поиск руководством государства в последние годы новой самоидентификации России, «поворот на Восток», на превращении ее в евразийский центр силы, объясняются причины отхода от западноевропейской ориентации. Высказываются прогнозы политики восточного поворота, ее будущего влияния на развитии Сибири и Дальнего Востока.

Ключевые слова: Россия; евразийство; Азия; Европа; Евразия; АТР; русские; тюрки; неоевразийство; идеократия; «поворот на Восток»; евразийский центр силы мировой политики.

\section{Для цитирования}

Осинский И. И. Россия — центр «Большой Евразии» // Евразийство и мир. 2020. № 1. C. 3-15.

Одной из проблем, к которым не затухает общественный интерес, является евразийство. Зародившееся в среде русской эмиграции в 1920-1930-е гг. как социально-философское учение и идейно-политическое движение евразийство в течение столетия будоражит научную мысль, вызывая постоянные, временами весьма острые дискуссии. Ученые, политики, журналисты обсуждают возможность формирования интегрированной политико-экономической зоны, охватывающей огромный евразийский континент и роль в этом пространстве России как государства, якобы призванного выполнить особую миссию в судьбе народов данного континента и мира в целом.

Модель социально-политического устройства России евразийцы надеялись осуществить путем мирного преобразования коммунистического государства в автаркическое и авторитарное, руководимое элитой («правящим отбором»), опирающейся в своей политике на доминирующую идею евразийского культурного единства («идеократия»). В экономике предполагалось обеспечить гармоническое сочетание частной и государственной форм собственности. В духовной сфере интегрирующая роль отводилась православию. В Октябрьской революции 1917 г. евразийцы видели 
не только катастрофу, но и начало новой эпохи, связанной с выходом России из чуждого, как они считали, ей европейского культурного мира и вступлением на путь самобытного исторического развития, на путь, «поворота к Востоку».

Опубликованный ими в 1921 г. в Софии сборник статей «Исход к Востоку» стал первым манифестом евразийства, определивший стратегию этого движения. У истоков евразийства стояли такие видные деятели русского зарубежья, как лингвист князь Николай Трубецкой, философ и богослов Лев Карсавин, правовед Николай Алексеев, литературовед Дмитрий Святополк-Мирский, географ и экономист Петр Савицкий, музыковед Петр Сувчинский. В те годы в ряде европейских столиц (Париже, Берлине, Праге) издавались газеты и журналы евразийского направления.

Евразийство, как и многие социально-философские, идейно-политические движения, не избежало трудностей, противоречий и спадов. Тем не менее оно не упускало главной задачи, которую стремилось решить, - создание идеологии России, где были бы соединены в диалектическом единстве наука, религия и философия. При этом его представители опирались на взгляды своих предшественников-славянофилов. Критиковали европейскую цивилизацию за ее стремление представить свои ценности как общечеловеческие, допетровскую Русь, свою Евразию видели неким подобием православного царства. В своем проекте будущего государственного устройства России евразийцы предусматривали федерацию.

Идеи евразийства получили свое развитие во второй половине XX в. Существенный вклад в их разработку внес Л. Н. Гумилев. Изучая историю русского и тюркских народов, их взаимоотношения, он пришел к выводу, что в процессе формирования и развития Российской империи большую роль сыграли тюркские народы - казахи, киргизы, узбеки и др. Именно славяне и тюрки, считал Л. Н. Гумилев,- - эти два крупных суперэтноса составили основу российского государства. Концепция Л.Н. Гумилева нашла свое научное осмысление в его трудах «Этногенез и биосфера Земли», «Тысячелетие вокруг Каспия» и др. и была взята на вооружение многими представителями данного направления. Президент Казахстана Н. А. Назарбаев продолжил разработку евразийских взглядов. Он не только подтвердил вклад тюркских народов в развитие России, но и обосновал идею евразийства как основу формирования содружества независимых государств с целью развития экономических, политических и культурных связей между ними. При этом подчеркнул мысль о невозможности обособленного существования стран в современных условиях. Заявил, что Казахстан готов играть более значимую положительную роль в интеграции независимых европейских и центральноазиатских стран.

На рубеже XX-XXI вв. усилился интерес к евразийской концепции. После распада СССР в мире фактически установился однополюсный мир с единственным глобальным центром силы на земле - США. Соединенные Штаты Америки открыто перешли к политике с позиции силы, вмешательства в дела других государств, что не могло не вызывать естественного раздражения, в частности, России и Китая. Как следствие, среди определенных групп ученых и политиков ряда европейских и азиатских государств стали появляться различные концепции нового мирового устройства, в том числе оказалась востребованной концепция евразийства. Эта востребованность проявилась в выступлениях руководителей государств, в проведении международных научных конференций, в многочисленных публикациях, 
в формировании большого массива интернет-ресурсов, так или иначе посвященных евразийству.

В 1998 г. по инициативе М. С. Горбачева был проведен круглый стол под названием «Загадки Евразии: Россия в формирующейся глобальной системе», в которой участвовали ведущие международники России.

В июне 2014 г. в Улан-Удэ состоялась Х Международная научная конференция («Байкальская встреча») «Проблемы евразийства и интеллигенция», на которой было заслушано и обсуждено более ста докладов (материалы изданы в двух томах). Опубликован ряд монографий, научных статей известных исследователей, в числе которых М. Л. Титаренко «Россия лицом к Азии» (1998), Алекс Бэттлер «Россия на обочине мира (1999), «Евразия: иллюзии и реальность» (2018), А. Г. Дугин «Преодоление Запада // Основы евразийства» (2002) и др. Проблемы евразийства часто обсуждаются в «Независимой газете», других изданиях. В условиях кризисов интерес к данной теме приобретает новую динамику и расширяется круг ее изучающих.

Однако рост публикаций, выступлений по проблемам евразийства не означает выработку общих, согласованных позиций. По-прежнему отсутствует сложившаяся общепринятая концепция евразийства. Более того, частью исследователей сами термины «евразийство», «Евразия» рассматриваются как лишенные реальности, искусственные конструкты. «Это - мифы» утверждают некоторые из них. Так, канадский ученый А. Бэттлер, перу которого принадлежит около 500 научных и публицистических работ, в том числе 29 индивидуальных книг и монографий. В вышедшей недавно монографии «Евразия: иллюзии и реальность» пишет, что «участвуя на круглом столе (1998), я категорически выступил против концепции Евразии как искусственной и мифической, а посему никогда не реализуемой» [1]. «Аналогичной позиции, продолжает автор, придерживался и академик Г. А. Арбатов, который, не скрывая своего изумления, заявлял: «Это чисто географическое понятие? Если это так, какая, это к черту Евразия?... По-настоящему — это пшик». ...Не будет Евразии $[1$, с. 29]. «Столь же негативно в таком же ключе, пишет Бэттлер, выступил и крупнейший международник Н. А. Косолапов, справедливо утверждая, что Евразия не более чем географическое понятие. «В политическом и культурном отношениях такого явления, как Евразия, нет и никогда не было. ...Концепция "Россия в Евразии представляется мне тупиковой для России, причем для любой: демократической, диктаторской, рыночной, антирыночной, какой угодно"» [1, с. 46,47]. Столь же критической была оценка научных работников под покровительством академика Е. М. Примакова. В своей книге «АТР: мифы, иллюзии и реальность» (1997) А. Бэттлер пытается доказать отсутствие такого региона, в котором по определению не могло быть никаких интеграционных процессов [2, с. 12,13]. «Не может не потрясти, как считал А. Бэттлер, огромное количество государств, охватывающих чуть ли не половину земного шара быть превращенным в центр мировой экономики и политики. Неужели авторы не понимают, что слово центр означает точку, а в политическом смысле - государство, а не пространство» [2, с. 13].

Наряду с социально-философскими взглядами, отрицающими евразийство, Евразию, в 1990-е и последующие годы активизировался преимущественно конструктивный подход к данной проблеме, проявленный исследователями А. Г. Дугиным, А. В. Логиновым, С. И. Даниловым, А. С. Панариным, И. С. Исаевым и др. 
Как уже отмечалось, большое значение имела выдвинутая президентом Казахстана Н. А. Назарбаевым концепция евразийства и ее роль в интеграции европейских и центральноазиатских государств. Оценивая значимость данной концепции, академик НАН Казахстана Ж. М. Абдильдин подчеркнул: «Действительно, Казахстан является евразийской страной, центром евразийского континента. В географическом плане часть его территории находится в Европе, а другая часть расположена в Азии. Географическая среда, как известно, имеет определенное значение в понимании той или иной страны, характера и мировосприятия народа. Казахский этнос, его образующие роды и племена всегда жили в самых разнообразных климатических условиях. В великой степи представлено все географическое разнообразие: большие горы, леса, озера, пустыни и т.д. - все это формировало самобытную природу коренного этноса, который одинаково хорошо себя чувствует в самых разнообразных климатических системах» [3, с. 18-19].

Многие годы А. Г. Дугин занимается исследованием проблем евразийства, которое представляет собой систему взглядов классических концепций русского евразийства в сочетании с геополитическими концепциями, тезисами Р. Генона о превосходстве цивилизаций Востока над современной цивилизацией Запада, социально-политической системой взглядов европейского течения «Консервативной Революции», применением евразийских принципов к конкретной советской и российской политической ситуации [4, с. 11]. При всей широте подхода к трактовке евразийства и кажущейся привлекательности, концепция А. Г. Дугина, на наш взгляд, не получила всеобщего признания, о чем мы уже писали [5, с. 6-9]. Так, упоминавшийся нами академик НАН Казахстана Ж. М. Абдильдин пишет: «Евразийская идея А. Дугина выступает составной частью его имперского проекта. Он использует эту идею для обоснования концепции сверхгосударства в лице России, которая должна не только возвращать себе прежние территории, но и существенно расширять пределы будущей империи» [3, с. 18-19]. Трудно не согласиться с Ж. М. Абдильдиным в том, что евразийство - это, прежде всего форма интеграции для независимых государств с целью укрепления их экономических и культурных связей, а не форма, позволяющая расширять свою территорию за счет других без их согласия. После знакомства с евразийской концепцией А. Г. Дугина, его выступлениями создается именно такое впечатление - это неприкрытое подталкивание власть имущих России к присоединению, завоеванию других стран, прежде всего бывших союзных республик, ныне независимых государств. Но, оказывается, даже Россия в границах бывшего СССР не устраивает А. Дугина. Он, как свидетельствует его интервью с В. Познером (21.04.2014), выступает за присоединение к России всей Европы. «Нам надо захватить Европу, завоевать и присоединить. Давайте им скажем: под нашим протекторатом мы вам обеспечим защиту. Видите, как у нас сидят Pussy Riot? и ваших посадим. У Вас «фемен» бесчинствует в костелах, у нас быстро получают дубинкой и отправляются в грузовике в мусор или на историческую родину. Мы захватим Европу, и все высокие технологии - у нас. Вот оно развитие, вот она модернизация. Если вы хотели, вот она европеизация нашего общества» - зачитал высказывание А. Дугина во время интервью с ним В. Познер. Это свидетельствует о том, что евразийство Дугина - попытка идеологического обоснования политики, которая проводится современным российским режимом и оценивается мировой 
общественностью весьма критически. При этом следует подчеркнуть, что, согласно А. Дугину, в основе российской государственности должна лежать сверхзначимая идея. Такая общественная система именуется автором идеократией, то есть властью, основанной на идее. Российская власть обязательно должна иметь, как считает А. Дугин, свою идеологию. Почему в основе российской государственности обязательно должна лежать некоторая сверхзначимая Идея. И почему эта идея должна быть обязательно монистической, исключающей иную, тем более альтернативную точку зрения и политическую конкуренцию?

Дело в том, что власть, основанная на идее, сама является субъектом разработки данной идеологии как инструмента, позволяющего ей управлять народом, господствовать в обществе, подавлять несогласных с государственной идеологией. Пропаганда и насилие - неотъемлемые составляющие идеократии. «Идеократия,- - как справедливо подчеркивает Д. В. Орешкин,- всегда пропаганда и насилие. Они функционально необходимы друг другу. Насилие над текстами и над людьми» [6, с. 33].

Это естественно, так как идеология всегда нужна господствующему классу, его власти, как и средства насилия, особенно тогда, когда отсутствуют реальные результаты практической деятельности. Приходится, как замечает Д. В. Орешкин, упирать на идеологию.

Говоря о природе идеократических режимов, Д. Б. Орешкин пишет: «На практике так и выходит: идеократические режимы всегда создают замкнутые сакральные пространства, заполненные символами своей веры. Идейная (и не только идейная) жизнь в них строго регламентирована специальными канонами. Нарушителей ждет кара. Критика, выходящая за пределы базовых аксиом, рассматривается вместе с ее носителями. Изгоняется, предается анафеме. В современной Русской православной церкви даже появился новый красноречивый термин - «Каноническая территория». Чужим проповедникам на ней не рады» [6, с. 30]. В этой связи невольно возникает мысль не находится ли современное российское государство в столь трудном положении, когда «оно лихорадочно подбирает себе идеократические оправдания для репрессивных мер»? (Орешкин Д. Б.). И концепция А. Дугина является тем средством, которое предлагается современному российскому режиму.

При этом в общественном мнении культивируется вера в то, что наилучшей формой правления в России является идеократия.

Особый всплеск интереса к евразийству наблюдается в последние годы. В 2019 и 2020 гг. в «Независимой газете» были опубликованы статьи А. В. Лукина «Замысел о большой Евразии» и Н. В. Работяжева «Евразийство: шанс или тупик? Российскому обществу необходимая новая самоидентификация». Особенность этих публикаций заключалась в том, что в них идет речь о принятии российском руководством решения о превращении России в европейский центр силы, о мотивах и значении принятого решения.

В статье А. В. Лукина (руководитель департамента международных отношений НИУ «Высшая школа экономики», директор центра исследований Восточной Азии и ШОС МГИМО МИД России) «Замысел о большой Евразии» говорится о том, что курс на превращение России в независимый евразийский центр силы и мирового влияния сегодня стал официальной политикой Кремля и основным направлением мысли большинства российских экспертов по внешнеполитической стратегии. 
При этом автор сослался на слова Владимира Путина из Послания Федеральному собранию в феврале 2019 года: «Россия не может быть государством, если она не будет суверенной. Некоторые страны могут. Россия - нет. И она выбрала курс на создание собственного центра силы в Евразии». (Попутно заметим, что государственный суверенитет - основополагающий критерий любого государства. Если нет суверенитета, то нет и государства - И. О.). А. В. Лукин отмечает, что некоторые бывшие западники (С. Караганов) пишут об исчерпании Россией «европейской кладовой» и разрабатывают концепцию «Большой Евразии», в которой Россия займет центральное место.

Автором анализируются внешнеполитические факторы, которые, по его мнению, заставили высшую российскую власть отойти от западноевропейской ориентации и совершить «поворот на Восток». Концепция евразийства, разработанная рядом философов русского зарубежья в 20-х гг. прошлого века, в 1990-е гг. приобрела большую популярность в нашей стране.

По мнению политолога, в «евразийской идее есть ряд преимуществ». Прежде всего это стремление стать независимым евразийским полюсом мировой политики, что якобы соответствует исторической роли России. Далее, экономическая система нынешней России, в которой доминируют госкорпорации, в большей степени соответствует евразийскому экономическому идеалу, которым является «не рыночная экономика западного типа, но государственно регулируемая, с допущением частной инициативы в сельском хозяйстве и мелкой промышленности». Кроме того, присущий евразийскому миросозерцанию этатизм, полагает автор, вполне вписывается в российские традиции, ведь в нашей стране все прорывные реформы проводились «при помощи государства, которое играло самую активную роль в экономике» [7].

Реализация данной концепции, как считает А. В. Лукин, окажет благотворное влияние на развитие Сибири и Дальнего Востока. «Поворот к собственному региону и большое внимание к Азии,- - пишет он,-— может способствовать решению стратегической задачи России - развитию ее сибирских и дальневосточных регионов, задачи, многократно провозглашаемой и все еще очень далекой от реализации. С геополитическлй точки зрения превращение России в центр консолидации и интеграции Евразии будет способствовать обеспечению ее безопасности, созданию дружественного внешнего окружения, которое приведет к ее мирному политическому и эффективному экономическому развитию. Большую роль здесь призвано сыграть дальнейшее развитие и возможное расширение Евразийского экономического союза, его сопряжение с китайской инициативой Экономического пояса Шелкового пути, повышение эффективности Шанхайской организации сотрудничества, развертывание в сотрудничестве с Китаем проекта Большого евразийского партнерства» [7, с. 8].

Что касается точки зрения Н. В. Работяжева (канд. полит. наук, ведущий научный сотрудник ИМЭМО РАН), которая представлена нами в более развернутом виде, то следует отметить, что ее автор подчеркивает важность участия России в интеграционных процессах на постсоветском пространстве (прежде всего в рамках Евразийского экономического союза). В то же время он считает, что вопрос: может ли евразийство лечь в основу национальной идеи России и российской идентичности, нуждается в самом серьезном обсуждении, с чем нельзя не согласиться. 
В статье утверждается, что евразийская идеология формировалась под сильным влиянием концепции русского философа Николая Данилевского о «культурноисторических типах» (иными словами, локальных цивилизациях) и извечном противостоянии славянского и романо-германского миров. В основе евразийского учения лежали представление о грядущем «закате Европы», отрицание европоцентризма и вера в самобытный исторический путь России. Евразийцы утверждали, что Россия не является европейской страной, она есть Евразия - особый культурногеографический мир. Судьбы этого мира вершатся отдельно от жизни стран к западу от нее (Европа), а также к югу и востоку (Азия), хотя тяготеет Россия скорее к Азии. Поэтому Россия не должна идти по европейскому пути развития, у нее свой особый путь и особое предназначение [8].

Более того, как отмечает автор, романо-германский мир евразийцы рассматривали как злейшего врага России - Евразии. Они разделяли характерное для славянофильской мысли убеждение, что западный мир находится в состоянии упадка и гниения, а на смену ему идет мир российский, хотя, в отличие от славянофилов, утверждали миссию не столько славянского мира, сколько евразийского.

Русский народ, полагали евразийцы, нельзя сводить к славянскому этносу, с их точки зрения, он включает в себя «туранский» - тюркский элемент. Монголотатарское иго, по мнению евразийцев, было благом для России, поскольку именно от монголов русские переняли государственную идеологию и способность к объединению континента в единое государственное целое. В советской России, несмотря на ее официальную марксистскую идеологию, по словам Николая Трубецкого, проступает наружу «Россия подлинная, Россия историческая, древняя, не выдуманная славянская или варяжско-славянская, а настоящая русско-туранская Россия-Евразия, преемница великого наследия Чингисхана...

В статье Н. В. Работяжева справедливо отмечается, что евразийству присущи органические представления об обществе и государстве, а также сильные антиперсоналистические, антилиберальные и этатистские тенденции [8]. Так, евразийцы признавали реальность коллективных «соборных», «симфонических» личностей, в частности, Евразия была для них не только особым культурно-географическим миром, но и своеобразной «симфонической личностью».

Евразийцы полагали, поясняет автор, что в силу своих цивилизационнокультурных особенностей и геополитической судьбы Россия не может стать либеральной парламентской демократией, ей предначертан путь идеократической государственности. Идеократия, по мысли евразийцев, представляет собой такой социально-политический строй, при котором правящий слой формируется не путем периодических выборов, но «отбирается по признаку преданности одной общей идее-правительнице» (Николай Трубецкой). Власть при идеократии должна принадлежать организованной, сплоченной и строго дисциплинированной группе, которая будет объединена в единственную государственно-политическую организацию монопольно правящую партию со своей символикой и своей мистикой [8].

Идеократическое государство, в отличие от либерального, имеет свою идеологию и в силу этого непременно должно само активно организовывать все стороны жизни и руководить ими. 
Дается оценка экономическим воззрениям евразийцев, которые также были в значительной степени этатистскими, они склонялись к «плановой государственночастной системе хозяйства» и выступали за экономическую автаркию. Отстаивавшаяся ими модель действительно по ряду параметров напоминает экономическую систему нынешней России.

Даже сталинская экономическая система вызывала у евразийцев определенные симпатии. Создание в СССР централизованной плановой экономики в годы первой пятилетки, полагал Петр Савицкий, означает конец российского подражания Западу. По его мнению, коммунисты, создавая в Советском Союзе самобытную автаркическую экономику, «делают евразийское дело». «Положительную цель пятилетки,- - писал он,- с максимальной точностью можно определить как строительство особого мира России-Евразии». И весьма показательно, что в дальнейшем левое крыло евразийцев (группировавшееся вокруг издававшейся во Франции газеты «Евразия») эволюционировало к национал-большевизму, а некоторые из них даже увидели в сталинском СССР воплощение евразийских идеалов.

Уже вскоре после их появления на свет евразийские теории были подвергнуты критике рядом выдающихся философов русского зарубежья. В статье Н. В. Работяжева анализируются и критические оценки евразийских теорий выдающимися философами русского зарубежья. Так, Николай Бердяев, пишет автор, не принимал радикальное антизападничество евразийцев, их враждебность к «романо-германскому» миру и его культуре. «Отношение евразийцев к Западной Европе превратно и ложно, и подобное отношение заслуживает наименования азиатства, а не евразийства», — писал Бердяев. Он отвергал евразийскую идею о том, что Россия должна быть замкнутым миром, отгороженным от Европы, поскольку такая установка противоречит русской всечеловечности и всемирности. Бердяев критиковал и выдвинутую евразийцами «туранско-татарскую» концепцию русской истории, полагая, что они подменяют русскую идею идеей туранской. Между тем, утверждал философ, «все будущее русского народа зависит от того, удастся ли победить в нем нехристианский Восток, стихию татарскую, стереть с лица русского народа монгольские черты Ленина, которые были и в старой России».

Федор Степун отвергал не только политические установки евразийцев. Он критиковал также их «туранскую» мифологию, подчеркивая, что Россия - не Азия и не Евразия, а своеобразная Восточная Европа.

В статье приводятся критические характеристики евразийства в конце 90-х гг. прошлого века Александра Солженицына и Виктора Аксючица.

Суммировав отмеченное выше, Н. В. Работяжев выделил те идеи евразийцев, которые представляются ему совершенно ошибочными и неприемлемыми. Во-первых, это «туранская» концепция русской истории, позитивное отношение к монголо-татарскому игу и тому наследию, которое оно оставило в сфере русской государственности и культуры. Евразийцы упустили из виду, что именно монголы уничтожили на Руси демократические вечевые начала (к середине XIV в. вече было практически ликвидировано во всех русских землях, за исключением Новгорода и Пскова) и отрезали Россию от Европы и протекающих в европейской культуре процессов. Татарское иго оказало негативное влияние на русскую государственность, способствуя ее эволюции по направлению к деспотизму. Историк Сергей Пушкарев 
полагал также, что татарское владычество, необходимость кланяться чуждой власти или гнуться и хитрить перед ней оказали вредное влияние на моральный характер русского человека.

Во-вторых, это радикальное антизападничество, объяснение темных сторон русской истории «европеизацией». Но ведь, как отмечал еще русский философ Владимир Соловьев, «чрез европейское просвещение русский ум раскрылся для таких понятий, как человеческое достоинство, права личности, свобода совести и т.д., без которых невозможно достойное существование, истинное совершенствование». Эти ценности отнюдь не являются «атлантскими», как их аттестуют некоторые неовразийцы, но вытекают из признания достоинства человека, его безусловных и неотчуждаемых прав.

В-третьих, это органическое понимание общества и антиперсонализм, ведущий к отрицанию самоценности каждой человеческой личности. Из них вытекают непонимание ценности индивидуальной свободы и ее формально-правовых гарантий, неприятие представительной демократии и политического плюрализма, симпатии к тоталитарным режимам, этатизм, вера в то, что наилучшей формой правления в России является «идеократия». Этатизм распространяется также и на сферу экономики, где признается желательной автаркия и «плановая государственно-частная система хозяйства» с большим государственно-капиталистическим сектором.

Но ведь и идеократическая государственность с монопольно правящей партией, и гипертрофированный этатизм, и автаркия, и железный занавес, и пафос служения коллективу — все это в отечественной истории уже было и, как известно, ни к чему хорошему не привело. Таким образом, евразийство не может стать ни проектом обустройства нашей страны, ни основой национальной идеи и российской идентичности независимо от того, куда направлен в данный момент внешнеполитический вектор российского руководства.

Формирование новой российской идентичности, по нашему мнению, должно опираться совсем на другие традиции - не на ордынско-авторитарные, а на вечевые, земские, демократические. Обретение российским обществом новой самоидентификации, в рамках которой либерально-демократические ценности будут находиться в гармонии с национал-консерватиными, создаст более благоприятные условиях и для участия нашей страны в интеграционных проектах в Евразии [8].

Приведенное нами содержание статей А. В. Лукина и Н. В. Работяжева требует серьезных размышлений. В то же время многие высказывания, оценки являются очевидными. Их нельзя не принять. Нельзя не согласиться с Н. В. Работяжевым, считающим совершенно ошибочным и неприемлемым радикальное антизападничество. Мы касались этой проблемы в статье «Евразийство и Европа» («Евразийство и мир». 1993. № 6).

Так, одним из традиционных обвинений евразийцами европейцев являлся, например, тезис о западном эгоизме, в индуалистическом стремлении отстаивать собственные, личные права и выгоды. Идеологи евразийства противопоставляли Западу гармонический образ Древней Руси, осененной православием, братскую любовь, солидарность людей, беспримерную однородность. Однако такое идеализированное изображение Руси, как подчеркивает профессор Леонид Люкс, при ближайшем рассмотрении оказывается несостоятельным. «Напряженность соци- 
альных отношений и многочисленные крестьянские восстания в допетровской Руси указывают на то, что древнерусское общество ни в коей мере не было воплощением гармонического идеала» [9, с. 107].

Нельзя отрицать или принижать влияния Европы на Россию. По мнению многих известных русских интеллигентов, включая часть евразийцев, оно было весьма существенным. Л. Люкс обращает внимание на то, что, несмотря на критику некоторых авторов европеизации, такие представители русского общества, как Бердяев, Степун, Федотов, Вейдле, считали петровские реформы единственно возможным путем развития России. «Сближение с Западом уберегло русскую культуру от полного застоя: без импульсов с Запада были бы немыслимы культурные достижения России 20-го столетия» [9].

Прав Л. Люкс и в том, что, несмотря на критику евразийцами Запада, идеологические и политические установки евразийства соответствовали определенным западным явлениям.

Нельзя игнорировать влияния на Россию Европы, ее экономики, культуры, науки и в последующие годы. В годы существования советской власти накоплен огромный опыт взаимовыгодного сотрудничества СССР с европейскими странами в различных областях общественной жизни. Логичным и ожидаемым было бы продолжение данного сотрудничества и после образования России как самостоятельного государства. К сожалению, этого не произошло. Причинами являются не только европейские государства, но и политика России. Об этом пишут многие исследователи. Например, польский профессор Х. Вальчак утверждает, что в последнее время в государственной политике России «появились новые проблемы, дающие повод для беспокойства и служащие одновременно толчком для новых научных исследований. Присутствующие в идеологии современного евразийства элементы радикального национализма и империального экспансионизма пропитывают современную заграничную политику России. Для нас, поляков, исторически опытных в общении с восточным соседом, это очень плохой знак» [10, с. 104].

Как мы уже отмечали, настороженность и даже тревога некоторых исследователей объясняются в том числе и тем, что в публикациях некоторых российских авторов нередко Европа представляется как некая враждебная сила России, русскому народу, а евразийство как изначально антиевропейское идейно-политическое течение, якобы призванное преодолеть влияния европеизма, внедренного в российскую действительность во времена Петра I и после.

Нельзя не учитывать и влияния на отношения Европы и России вмешательства России в дела других государств (Украина, Белорусь и некоторые другие), усиление элементов тоталитаризма внутри страны, что активизирует протестное движение среди части российских граждан, которое находит моральную поддержку в Европе.

Неприемлемым в евразийстве является органическое понимание общества и антиперсонализм, ведущий как справедливо утверждает Н. В. Работяжев, к отрицанию самоценности каждой человеческой личности. В этот ряд следует ставить такие вопросы, как ценность индивидуальной свободы, ее гарантии, неприятие тоталитаризма, этатизма, идеократии и ряда других. Включение же этих и подобных понятий в евразийство и реализацию их на практике означало бы движение России вспять, в прошлое. 
Обращает на себя внимание неоднозначная оценка исследователями «туранской концепции русской истории», «монгольского ига». Кроме упоминавшихся нами Л. Гумилева и Н. А. Назарбаева, которые положительно оценивают указанные исторические факты в истории России, аналогичной или близкой точки зрения придерживаются и ряд известных ученых. Так, сибирские исследователи Ю. В. Попков и Е. А. Тюгашев пишут, что в генезисе евразийской проблемы важное значение имеет не только географический, но и антропологический аспект, а в известном смысле - и социально-гуманистический аспект. Авторы ссылаются при этом на одного из основоположников евразийства Н. С. Трубецкого, который писал: «Связь русских с туранскими закреплена не только этнографически, но и антропологически, ибо в русских жилах, несомненно, течет, кроме славянской и угрофинской, и тюркская кровь» $[11$, с. 138]. И далее Ю. В. Попков и Е. А. Тюгашев продолжают: «Но этот факт считался настолько обычным и очевидным для русского народа, что евразийцы не придали ему особого значения. На наш взгляд, евразийская проблема в том виде, как она возникла в результате европейской колонизации стран Азии, является одним из источников евразийского учения» [12, с. 14$]$.

В «Словаре философских терминов» указано: «Россия должна рассматриваться как наследница Великой монгольской империи Чингисхана, провинцией которой она являлась на протяжении четверти тысячелетия. Такие атрибуты Великой монгольской империи, как жесткая государственность, единоначалие, приоритет военной мощи, служение подданных великой идее, жертвенность и вместе с тем терпимость, отсутствие социальных и сословных ограничений при формировании власти, равенство перед законом, вошли в качестве социального инстинкта в самосознание российскоевразийского народа, определили его социальную психологию и поведение» $[13$, с. 142]. В то же время нельзя игнорировать того факта, что монгольские завоевания были страшным игом для подвластных ему народов.

Можно продолжить перечень различных трактовок, оценок указанных выше понятий, фактов, что свидетельствует о том, что евразийская концепция еще полностью не сформирована, в том числе не определено содержание самого понятия «евразийство». Это требует серьезного научного поиска в направлении выработки евразийской концепции. По мнению специалистов, евразийские страны, что особенно важно, имеют необходимые предпосылки для интеграции в различных областях общественной жизни: экономике, социальной, духовной, военной сферах.

В экономике - наличие природных ресурсов, развитой промышленной системы, либеральных рыночных отношений в сфере мелкого и среднего бизнеса, но слабый уровень внедрения и разработки новейших технологий в индустриальной инфраструктуре.

В социальной сфере - большинство народов Евразии, включая русский народ, в значительной мере продолжает оставаться разновидностями традиционного общества, где коллективные, соборные, общинные принципы преобладают над индивидуализмом и приватной сферой. Формы этой общинной социальности во всех случаях различны, но сам факт ее наличия дает прекрасные культурно-этические основания для того, чтобы евразийские идеи получили широкую поддержку у населения этих стран. 
В военной области - все страны Евразии имеют свои вооруженные силы. Между рядом государств заключены договоры о коллективной безопасности. Укрепление сотрудничества в военно-стратегической области, а в перспективе выход на создание общеевразийской системы коллективной безопасности станут общим достоянием и укрепят общие рубежи, усилят позиции на международном уровне [14, с. 4].

Перечисленные предпосылки свидетельствуют о том, что Евразия является регионом, располагающим большими возможностями для реализации совместных энергетических, транспортных, финансовых и других проектов в интересах, живущих в нем народов.

В развитии идей евразийства важно исходить из того, что Евразия - это не узколокальное образование, а максимально широкое, охватывающее весь евразийский контингент. В континентальную евразийскую интеграцию, под которой понимается качественный рост экономических, политических и социальных связей между регионами Еразийского суперконтинента, будут включены Европа, Северная и Центральная Евразия, Восточная, Южная и Западная Азия [16, с. 34]. Реализация намерения превращения России в независимый евразийский центр силы и мирового влияния потребует огромных усилий и мудрости от политического руководства и всего российского народа. Прежде всего необходимо обеспечить высокий уровень экономического, научно-технического, социального развития России, взвешенной, разумной стратегии в области внешней политики, добиться добрососедских отношений с другими народами. Без решения перечисленных проблем трудно стать во главе «Большой Евразии».

Огромное значение будет иметь достижение российско-китайского взаимодействия и взаимодействия и с западными странами.

\section{Литература}

1. Бэттлер Алекс. «Евразия»: иллюзии или реальность. М.: ИТРК, 2018. С. 117-128.

2. Арин О. А. Азиатско-тихоокеанский регион: мифы, иллюзии. М.: Флинта, Наука, 1997. C. 13, 18-19.

3. Абдильдин Ж. М. Евразийство как развивающееся понятие // Філософія. Політологія. 2011. № 105. С. $17-19$.

4. Осинский И. И. Некоторые проблемы евразийства и интеллигенция // Проблемы евразийства и интеллигенция: материалы X Междунар. науч. конф: в 2 т. / отв. ред. И. И. Осинский. - Улан-Удэ: Изд-во Бурятс. госун-та.. 2014. Т. 1. С. 11.

5. Осинский И. И. Евразийство и Европа // Евразийство и мир. 2017. С. 6-9.

6. Орешкин Д. Б. Евразийство. Идеократия. Мир наизнанку // Евразийство и мир. 2017. № 1. С. 33 .

7. Лукин А. В. Замысел о большой Евразии [Электронный ресурс] // Независимая газета. 2019. URL: https://www.ng.ru/ideas/2019-03-04/7_7523_ideas.html (дата обращения: 09.10.2020).

8. Работяжев Н.В. Евразийство: шанс или тупик? [Электронный ресурс] // Независимая газета. 2019. URL: https://www.ng.ru/ideas/2019-04-03/5_7547_eurasia.html (дата обращения: 09.10.2020).

9. Люкс Л. Евразийство // Вопросы философии. 1993. №6. С. 144-154.

10.Вальчак Х. Международное евразийство в современной польской научной литературе: состояние исследований // Евразийство и мир. 2015. № 1. С. 104.

11. Трубецкой Н. С. История. Культура. Язык. М., 1995. С. 138 
И. И. Осинский. Россия - центр «Большой Евразии»?

12. Топков Ю. В., Тюгашев Е.А. Феномен евразийства // Евразийство и мир. 2013. № 2. C. 14.

13. Словарь философских терминов.М., 2004. С. 142.

14. Селезнев Г. Международные аспекты евразийства // Евразия. 2001. № 1. С. 4.

15. Винокуров Евгений. Прагматическое евразийство // Россия в глобальной политике. 2013. T. 11, № 2. С. 34.

\section{IS RUSSIA A CENTER OF GREATER EURASIA?}

\section{Ivan I. Osinsky}

Dr. Sci. (Philos.), Prof.,

Dorzhi Banzarov Buryat State University

24a Smolina St., Ulan-Ude 670000, Russia

intellige2007@rambler.ru

Abstract. The article deals with the problems of developing socio-philosophical concept of Eurasianism: the reasons, conditions, factors, contradictions in the formation of this doctrine, and its main ideas. We have considered the contribution of scientists and policymakers to its development, discussions around the concepts of "Eurasianism", "Eurasia", "The Asia-Pacific". Besides, the article analyzes the attitude of the Eurasians to the 1917 revolution, Soviet power, reforms in the field of economics, culture, and education. It is comprehended the concept of "ideocracy", its essence, and place in the Eurasian concept. Attention is drawn to the search by the government for a new selfidentification of Russia, to its transformation into a Eurasian centre of power, to the reasons for the departure from the West European orientation, and Asia pivot. We have explored trends and project the future of the "turn to the East", its influence on the development of Siberia and the Far East.

Keywords: Russia; Eurasianism; Asia; Europe; Eurasia; the Asia-Pacific; Russians; Turks; neo-Eurasianism; ideocracy; "turn to the East"; the Eurasian power-centre of world policy.

Статья поступила в редакцию 10.03.20; одобрена после редактирования 30.03.20; принята к публикации 30.10.20. 